\title{
Sharia Retail Competitiveness and Consumers' Behavior: Should Sharia Retail Capitalize Islam?
}

\author{
M. Elfan Kaukab ${ }^{1 *}$, Aksamawanti $^{2}$, Machfudz $^{2}$ \\ ${ }^{1}$ Faculty of Economics Universitas Sains Al-Quran Jawa Tengah, Wonosobo, Indonesia \\ ${ }^{2}$ Faculty of Sharia and Law Universitas Sains Al-Quran Jawa Tengah, Wonosobo, Indonesia \\ *Corresponding author.Email: elfan@unsiq.ac.id
}

\begin{abstract}
This research aims to formulate the sharia retail marketing framework, focusing on minimarkets and supermarkets capitalizing Islam to sustainably compete with conventional retail. To reach the goal, literary reviews on neuromarketing and the Islamic perspective of consumerism were carried out. After that, we build a framework and use it to evaluate recent Islamic branded stores conditions. Islamic stores reviewed located in Jakarta, Indonesia. The result shows that Islamic stores lack neuromarketing determinants (color, light, sound, spatial arrangement, and aroma). Therefore, we propose strategical implications taken by sharia retail in reaching competitiveness by means of developing a sharia marketing that fulfills the neuromarketing as well as social identity requirements. This article should help sharia-based retail practitioners to better understand good marketing strategies and their relevance to Islamic teachings. They should be able to adopt the strategies and build successful and sustainable sharia retails.
\end{abstract}

Keywords: sharia retail, conventional retail, marketing strategy, Islam capitalization, consumers'

behavior

\section{INTRODUCTION}

Retail business in Indonesia has been enjoying a significant increase. Indonesian Bank noted 7,7\% growth in December 2018, which was bigger than the previous year's 3,4\% growth rate [1]. In March 2019, consumer spending grew $5,1 \%$ year on year, reflecting light inflation and healthy employment [2]. In the last five years, $46 \%$ of Indonesian consumers admit that they have spent more money on daily needs [3].

Islamic retail, a business of consumer goods using brands associated with Islamic teachings, is a new trend blooming in Indonesia. This retail is characterized by Islam-related customs, such as Islamic names, green paint, Arabic typography, less activity in prayer times, zakat and alms campaign, consumers' reception, and so forth. This is actually in line with the general trend of the Indonesian brand that attempts to lift the local's dignity and provides consumer-adaptive service [4]. Examples of these brands are Supermarket Selamat, 212mart, Supermarket Berkah, Akhsan Halal, De'Halal, Tip Top, and so forth. Supermarket Selamat even has both "Moslem" and "indigenous" brands. There have been some Islamic retail brands but they do not have adequate competitiveness [5]. The new trend seems to bring no real change. Stores are operational without many customers although they sell a large number of goods with the same quality as the more established retails like Alfamart and Indomaret. Top Brand Award survey measuring the mind share, market share, and commitment share revealed that $88,1 \%$ minimarket share is dominated by Alfamart and Indomaret. Only one Islamic brand supermarket succeeded in Top Brand Award, Tip Top, with brand index 11,7\%. It sits in second place after Giant $(17,6 \%)$ [6]. Note that Tip
Top, despite claiming as Islamic supermarket, does not use Islamic brand.

New passion in Islamic retail seems to bring no significant change in sharia retail business competitiveness in general, but it connects to the relatively monotonous design. These businesses appear to focus on the surface characteristic disregarding the marketing aspect.

From the marketing point of view, this is an unfortunate situation since Islamic identity deserves to be commercialized. Nearly $90 \%$ of the Indonesian population are Moslems and the sharia economy is generally getting better. The Islamic retail business's inability to get consumers reflects the retail practitioners' inability to attract people's interest despite advancing the Islam identity in branding.

Modern supermarket and minimarket are intensively applying behavior-based marketing [7]. It can be seen in the bright color, especially red, orange, and bright yellow, used in the signpost, the exterior and the interior; bright lighting in the store; fresh produce placement near the entry; vibrant music; periodically-altered product placement and movement barrier to slow consumers' movement that lead to the increasing probability of consumers' buying unnecessary items, comforting scent, cool temperature, and so forth [8][11].

The unrevealing of the stores' tricks are the results of scientific research on consumers' behavior, whether on the scientific literature on neuromarketing or the company's internal affairs. The underlying condition is that human behaviors are mostly determined by the basic instincts developed revolutionary [12]. The instincts include being fond of bright colors, bright lighting, shiny things, fresh aroma, narrow lanes, and so on. 
The behavior applies to both Moslem and non-Moslem consumers. The universal human nature is natural and wellexploited by retail stores around the world. These instincts are more primeval and more deeply rooted than social identities like religion, wealth, and tribe [13].

Nevertheless, social identity is the one exploited by Islamic retail. It is true that social identity has taken part in buying decision-making made by the Moslem [14]-[17], although it is not a sole factor. The exploitation has been so intense that it disregards the consumers' more natural aspects. The observation of supermarket' brand colors can immediately address this. While religious identity is advanced, the counterproductive aspects are also surfaced.

The color choice seems to have deep evolutionary roots. Yellow and red are clues on ripe fruits in nature that trigger the instinct to approach them. The colors also symbolize energy to start the day and be active. On the other side, green is not arousing as the primordial life was dominated by green leaves [19]. Meanwhile, freshness stimulates people to be more vibrant, encouraging the placement of fresh fruits and vegetables near the entrance of modern stores.

Cool colors obviously are important for other purposes, like for stores where the consumers are not rushing [20]. The environment with a cool color comforts the consumers inside it, as in Super Indo or Hero. This applies in the supermarkets oriented to direct customers with large incomes and more free times as they will likely spend more time and money there. The condition is counterproductive to minimarket visited by rushing customers with less money. Sparkling light is preferred because, in the old times when human ancestors hunted for a water source, the sparkling light was a sign of a water source.

Since Islamic supermarkets used religion as a brand element, this raises incompatibility potential between marketing techniques and Islamic teachings [21]. In the consumption aspect, Islamic teachings legalize the buying and selling of halal products and forbid exaggeration, vanity, usury, consuming intoxicating goods, and hurting body and soul [22]. They can be regarded as the Islamic ethical elements in consumption. Islam forbids consumption when it contains usury, or it consists of illegitimate items (such as pork, alcohol, stolen goods, etc.), or it aims to brag oneself in front of other people, or it exceeds the limit of proper consumption.

The last point, exaggeration, contradicts to impulsive buying concept. Impulse buying is a shopping behavior in which the decision to buy things is based on wants rather than needs. However, not all that is wanted is exaggerated. In a system where the retails only sell halal products, the productions sustain the poor society's welfare and needs. Thus, impulsive buying contributes positively to collective Moslem and is acceptable especially in Islam supermarkets and minimarkets. It has been known that impulse buying is controlled by emotion [23] and Islamic positive emotion should help to boost the sharia-based impulse buying.

The relationship between individual consumption and collective Moslem brings us to the concept of the Islamic economy. It is a system different from a capitalist economy as it is in a cycle and collective. 'In a cycle' means that the financial system sustaining the economic system is a usuryfree one. Therefore, the excess money is invested instead of kept to produce interests. 'Collective' means that the economic activities are interrelated between individuals and the market. The economic system provides feedbacks to the overall society in the form of ZISWAF (zakat, infak, sedekah/alms, and wakaf). These ensure that the economic system runs as a system that develops and increases social welfare. Islamic economic system potentially alters into an inclusive and sustainable system that provides solutions for the world's contemporary economic problems [24]. The feedback is similar to social responsibility system (CSR) in the context of the capitalist economy, which has been proven to play a role in boosting purchase, even in companies with bad image [25], [26]. Likewise, ZISWAF also encourages the consumption of Moslem costumers that see Islam as an ethical ideology [27] or as a unifier of social distance [28]. The situation leads to the importance of competitiveness conceptualization of sharia retail's competitiveness to make it possible for them to compete with modern supermarkets and minimarkets. The key lies in how Islamic retail can manage environmental aspects to encourage positive consumers' behavior. When the environmental aspect is discussed, sensory elements like the color, lighting, sound, layout, and aroma come up. Related to the sound aspect, there have been debates on how music can be utilized in Islamic teachings. The general opinion holds that so long as the lyrics contain no immoral elements, vibrant and lively music commonly played in the supermarkets can be used [29].

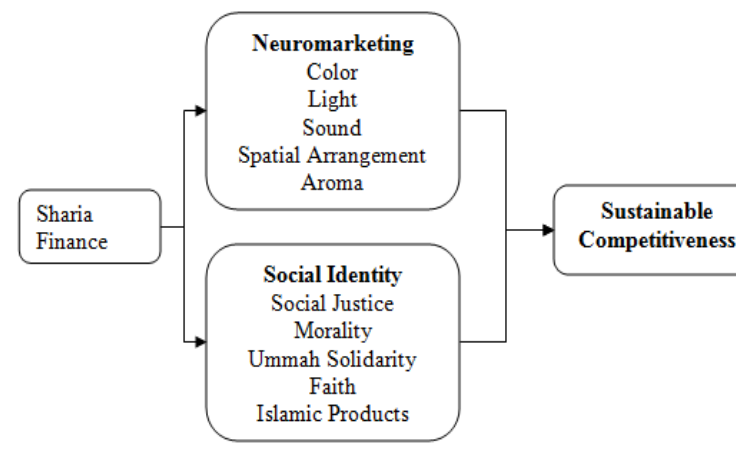

Figure 1 Islamic Retail Competitiveness Conceptual Framework

We conceptualize social identity elements to include social justice, morality, solidarity, faith, and Islamic products. Social justice is the retail's social orientation in the form of ZISWAF commitment, apart from personal profit. Related to the product price, retailers can decide whether to sell the products cheaply, like Tip Top that commits to taking only $2-3 \%$ profit [30] as a form of social justice for Moslem society. They can also sell at a normal price with some revenues set aside for ZISWAF. Morality refers to the good service quality aspect along with the added values of Islamic teachings related to courtesy and friendliness. Ummah solidarity refers to how retail can also buy and sell products of Moslems, especially those who are poor and in need. Faith relates to obligatory rituals such as sholat (prayer), azan (call to prayer), zikr (remembrance), salam (greeting), and so forth. Islamic products include Moslem specificallyconsumed products like Al Qur'an, books on religions, prayer equipment, and so on. These, of course, are merely additional common consumer products. 
We also include sharia finance as a source of sharia retail to make the connection between Islamic retail and Islamic economy clear. The sharia finance should also lower products' selling price because there is no interest or fine burdening retailers.

Neuromarketing is a competitiveness booster element, placing sharia retail in a decent position to compete with capitalist retails. It follows the knowledge-based view (KBV) stating that knowledge is the source of competitive advantages. Rare, inimitable, irreplaceable, and valuable resources are required to achieve that competitiveness [32]. This can be fulfilled with Islamic social identity aspects. This obviously is valuable. The rarity, inimitability, and irreplaceability refer to specific aspects of Islamic teachings that are applied creatively and knowledgeably by the retailers.

\section{METHODS}

We perform observations on six Moslem branded retail stores and six conventional retail stores in DKI Jakarta. The observations carried out based on the framework checklist. Hence, for all stores, we check for neuromarketing aspects (color, light, sound, spatial arrangement, and aroma) and social identity aspects (social justice, morality, ummah solidarity, faith, and Islamic products). The results then descriptively presented to evaluate the application of Islamic retail competitiveness framework.

\section{RESULTS AND DISCUSSION}

For the color evaluation, we found that Islamic-based retails commonly use green dominated colors instead of red and yellow. Green, purple, and dark blue are cold colors discouraging people to stay in a long time in the stores [18]. Some even use black that makes the stores dark and gloomy. It is counterproductive when the stores want to boost large consumption.

Light in Islamic retail stores sharply contrasts with conventional stores. There is minimum lighting in the store. The lighting level in minimarkets like Alfamart and Indomaret reaches 600 lux, while, according to the researchers' measurement, the lighting in Moslem minimarket ranges in 100-200 lux. At several points, 10-lux lighting even available.

For sound, spatial arrangement, and aroma, we found no difference between Islamic and conventional supermarkets. However, we found differences in all aspects of social identity except social justice. For social justice aspect, Islamic stores and conventional stores used some donation boxes for orphanages, mosques, or national ZIS agency $(B A Z I S)$ funds. Islamic stores did differ because they have donation offer for international funds such as Gaza refugees. However, conventional stores also have their own unique donation scheme, apparently part of their CSR (Corporate Social Responsibility). Hence, both actually not differ in terms of social justice issues.

Islamic stores differ from conventional stores in terms of morality, ummah solidarity, faith, and Islamic products. As we expect, Islamic stores sold products from Islamic branded SME, among other conventional products. Several of these products are religious items. They also remind consumers about prayer time and dressed in Islamic way. Nevertheless, the difference in morality aspect actually inverted. Employees in conventional stores more courteous than employees in Islamic stores. They are trained to perform standard procedures for service quality to customers. Meanwhile, employees from Islamic stores seem unable to be polite in the level of conventional stores standard. Some unable to focus to serve consumers and busy for their own business such as chit-chat or checking their cellphones.

The findings show that Moslem minimarkets need to pay more careful attention to visual aspects and customer service quality. This makes Moslem minimarkets lack behind conventional supermarkets. Studies found that illumination important for good consumer response [12] but Islamic supermarkets use minimal lighting, making them unable to compete with conventional supermarkets, especially in night hours. Research also found that ambiance factors importance for store attractiveness [8]. Ambiance factor from colors also unable to influence consumer behavior, because the colors not bright but also not elegance.

A consumer perspective on CSR also important for retail stores [26] and they capitalize on it for their profit. Islamic teaching, which has CSR embedded in their faith, seeming unable to capitalize this better than conventional stores. Hence overall, Islamic supermarkets still far from being the winner in retail competition.

\section{CONCLUSION}

The above findings show that Islamic retails lack behind conventional stores in terms of visual elements such as colors and lighting and customer service. Islamic retails can enhance competitiveness yet still maintain Islamic consumption ethics by increasing their visual appeal and customer service. They should begin to adopt various elements of the conceptual framework in the present research.

\section{REFERENCES}

[1] Indonesia Investment, "Strong Growth of Retail Sales in Indonesia in December 2018," Indonesia Investment, 2019. [Online]. Available:

https://www.indonesiainvestments.com/id/news/todays-headlines/stronggrowth-of-retail-sales-in-indonesia-in-december2018/item9089? [Accessed: 09-Sep-2019].

[2] Insider Stories, "Indonesia's Retail Sales Grow 10.1\% in March,” Insider Stories, 2019. [Online]. Available: https://theinsiderstories.com/indonesiasretail-sales-grow-10-1-in-march/. [Accessed: 08-Sep2019].

[3] Nielsen, "Indonesia is in the Top 3 Markets with the 
Environmental Concern and Support for Environmental Action," Psychol. Sci., vol. 27, no. 10, pp. 1331-1339, 2016 .

[14] M. M. Islam and M. A. F. Chowdhury, "Consumers' buying decision process toward halal product : a study in Bangladesh,” Int. J. Bus. Innov. Res., vol. 16, no. 3, pp. 285-301, 2018.

[4] K. Cooke, "BrandZ" TM Top 50 Most Valuable Indonesian Brands increase $4 \%$ in overall brand value to $\$ 84$ billion," Kantar, 2019. [Online]. Available: https://uk.kantar.com/business/brands/2019/brandztop-50-most-valuable-indonesian-brands-increase-4per-cent-in-overall-brand-value-to-84-billion-dollars/. [Accessed: 09-Sep-2019].

[5] D. A. Muthmainah, "Forecasting the fate of 212 marts amid the sluggish retail industry (Meramal Nasib 212 Mart di Tengah Lesunya Industri Ritel)," CNN Indonesia, 2018. [Online]. Available: https://www.cnnindonesia.com/ekonomi/ 20180316091815-92-283494/meramal-nasib-212-martdi-tengah-lesunya-industri-ritel. [Accessed: 09-Sep2019].

[6] Top Brand Award, “Top Brand Index,” Top Brand Award, 2019. [Online]. Available: https://www.topbrand-award.com/top-brand-index/. [Accessed: 08-Sep-2019].

[7] C. Brinkworth, "Supermarket savvy: An analysis of psychological exploitation within grocery stores," 2017.

[8] N. P. Abimnwi and R. K. Njuguna, "An Analysis of In-Store Environment Ambience Factor Influence on Consumer Behaviour," Int. J. Sales, Retail. Mark., vol. 4, no. 6, pp. 31-44, 2015.

[9] T. Mansson, "Energy in supermarkets -An overview of the energy flows and refrigeration controls," Chalmers University of Technology, 2016.

[10] K. Vissers, "Influencing Healthy Food Choices in the Supermarket: An Experimental Study Using Virtual Reality," University of Twente, 2018.

[11] Y. A. Soomro, S. A. Kaimkhani, and J. Iqbal, "Effect of visual merchandising elements of a retail store on consumer attention," J. Bus. Strateg., vol. 11, no. 1, pp. 21-40, 2017.

[12] J. Bercik, E. Horska, W. Y. R. Wang, and Y.-C. Chen, "How can food retailing benefit from neuromarketing research : a case of various parameters of store illumination and consumer response," in 143rd Joint EAAE/AAEA Seminar, 2015.

[13] K. Eom, H. S. Kim, D. K. Sherman, and K. Ishii, "Cultural Variability in the Link Between
[15] D. Mathras, A. B. Cohen, N. Mandel, and D. Glen, "The effects of religion on consumer behavior : A conceptual framework and research agenda," J. Consum. Psychol., vol. 26, no. 2, pp. 298-311, 2016.

[16] W. I. M. Fauzi, S. S. M. Mokhtar, and R. Z. Yusoff, "An Exploratory Study of Muslim Consumers ' Expectation of an Islamic - Based Retail Store and Their Patronage Motive," in ISSC 2016 : International Soft Science Conference, 2016, pp. 731-736.

[17] V. Yeniaras and T. N. Akarsu, "Frugal doesn't mean ordinary: a religious perspective," J. Islam. Mark., vol. 8, no. 2, pp. 204-217, 2017.

[18] W. Tantanatewin and V. Inkarojrit, "Effects of color and lighting on retail impression and identity," J. Environ. Psychol., vol. 46, pp. 197-205, 2016.

[19] M. C. Casas and J. Chinoperekweyi, “Color Psychology and Its Influence on Consumer Buying Behavior: A Case of Apparel Products," Saudi J. Bus. Manag. Stud., vol. 4, no. 5, pp. 441-456, 2019.

[20] K. Randhawa and R. Saluja, "Does Visual Merchandising have an Effect on Consumer Impulse Buying Behavior?,” J. Gen. Manag. Res., vol. 4, no. 2, pp. 58-71, 2017.

[21] W. I. M. Fauzi, N. Zakaria, S. S. M. Mokhtar, R. Z. Yusoff, and M. Yusr, "Evaluating Relationship between Islamic Store Image and Malay Muslim Consumer Attitudes' in Patronizing a Store," Int. J. Supply Chain Manag., vol. 7, no. 6, pp. 108-113, 2018.

[22] I. Amalia, W. Riani, and A. Julia, "The Influence of Religiosity Values on Happiness with Islamic Consuming Ethics as Moderator Variable," Procedia Soc. Behav. Sci., vol. 219, pp. 76-83, 2016.

[23] C. Achar, J. So, N. Agrawal, and A. L. Duhachek, "What we feel and why we buy: the influence of emotions on consumer decision-making," Curr. Opin. Psychol., vol. 10, pp. 166-170, 2016.

[24] M. I. Ariffin, "Rethinking Islamic Economics and Finance: Paving the Way Forward," Int. J. Econ. Manag. Account., vol. 25, no. 2, pp. 153-171, 2017. 
[30] Moneysmart, "5 Business inspirations from TipTop Islamic Supermarkets (5 Inspirasi Bisnis dari Supermarket TipTop yang Tampil Islami)," Moneysmart, 2018. [Online]. Available: https://www.moneysmart.id/5-inspirasi-bisnis-darisupermarket-tiptop-yang-tampil-islami/. [Accessed: 09Sep-2019].

[31] K. Mejri, J. llexander MacVaugh, and D. Tsagdis, "Knowledge configurations of small and medium-sized knowledge-intensive firms in a developing economy : A knowledge-based view of business-to-business internationalization," Ind. Mark. Manag., vol. 71, pp. 160-170, 2018.

[32] A. L. Paulus and P. S. Murdapa, "The Utilization of Resource-Based View Theory on Minimarket Retail: Its Implication Toward Strategy and Competitive Advantage," in The 1st International Conference on Economics, Education, Business, and Accounting (ICEEBA 2016), 2016, pp. 220-227.

[29] Q. H. Ahmad and R. Mahmood, "Legitimacy and Illegitimacy of Music in Islam," Al-Qalam, pp. 79-89, 2018. 